\title{
Plant densities and harvesting times on productive and physiological aspects of Stevia rebaudiana Bertoni grown in southern Brazil
}

\author{
ERIK N. GOMES ${ }^{1}$, DIEGO MOTERLE ${ }^{2}$, LUIZ ANTONIO BIASI ${ }^{1}$, HENRIQUE S. \\ KOEHLER ${ }^{1}$, LUIZ ALBERTO KANIS ${ }^{2}$ and CÍCERO DESCHAMPS ${ }^{1}$ \\ ${ }^{1}$ Universidade Federal do Paraná, Setor de Ciências Agrárias, Departamento de Fitotecnia e Fitossanitarismo, Programa de Pós- \\ Graduação em Agronomia, Produção Vegetal, Rua dos Funcionários, 1540, Bairro Juvevê, 80035-050 Curitiba, PR, Brazil \\ ${ }^{2}$ Universidade do Sul de Santa Catarina, Departamento de Ciências Biológicas e da Saúde e \\ de Ciências Sociais Aplicadas, Programa de Pós-Graduação em Ciências da Saúde, Avenida \\ José Acácio Moreira, 787, Bairro Dehon, 88704-900 Tubarão, SC, Brazil
}

Manuscript received on July 4, 2017; accepted for publication on November 4, 2017

\begin{abstract}
Stevia (Stevia rebaudiana Bertoni) is a species characterized by producing non-caloric substances with high sweetening potential. Among these substances, rebaudioside A and stevioside are produced in greater quantity. Plant density and harvesting time are factors that affects biomass and sweetening compounds yield in this species. The objective of this research was to evaluate the effect of plant densities and harvesting times on the productive and physiological characteristics of stevia in southern Brazil. The experimental design was in randomized blocks, in a split-plot scheme, with 9 treatments comparing the effect of three planting densities ( 166667,83333 and 33333 plants ha $^{-1}$ ) in the plots and three harvesting periods (before, in the beginning and in full flowering) in the subplots. Harvesting at the beginning of flowering promoted higher dry leaf biomass yield and, when associated with the lowest planting density, promoted higher levels of rebaudioside A and stevioside. The lowest planting density resulted in greater leaves biomass accumulation, whereas the highest density promoted higher yields per area. Interaction between density of 166667 plants ha $^{-1}$ and the harvest at the onset of flowering promoted higher yields of rebaudioside A $\left(43.22 \mathrm{~kg} \mathrm{ha}^{-1}\right)$ as well as higher rebaudioside $\mathrm{A} /$ stevioside ratio $(0.60)$.
\end{abstract}

Key words: diterpene glycosides, natural sweetener, rebaudioside A, stevioside.

\section{INTRODUCTION}

Stevia rebaudiana Bertoni, popularly known as stevia, sweet grass or honeyleaf, is an herbaceous shrub belonging to the Asteraceae family, native to northeastern Paraguay, with natural occurrence also in the neighboring regions of Brazil and Argentina (Lemus-Mondaca et al. 2012).

Correspondence to: Erik Nunes Gomes

E-mail: e93gomes@gmail.com
The plant is becoming increasingly important as an agricultural crop due to the production of secondary metabolites named diterpene glycosides or steviol glycosides, with high sweetening potential and no calorific value. The most important commercially available glycosides, stevioside and rebaudioside A, are known to be around 300 and 400 times sweeter than sucrose, respectively (Lemus-Mondaca et al. 2012, Mandal et al. 2013). 
For industrial processing purposes, a higher concentration of rebaudioside A over stevioside is desired because the latter has a strong bitter residual taste, a characteristic not appreciated by the market (Yadav et al. 2011).

Commercial stevia cultivation occurs mainly in Asia and America. As per the regional analysis, North America represents the most lucrative market, followed by Latin America and Asia-Pacific, excluding Japan. China has a lead over other countries regarding production capacity and export of stevia, globally. Low-cost of production and availability of skilled resource is a major factor driving the market growth (Mordor Intelligence 2017).

Globally, stevia market was estimated to value at US\$ 347.0 million in 2014 and expected to reach US\$ 565.2 million by 2020 . In terms of volume of consumption it is expected that stevia may reach 8506.9 tonnes by the end of 2020 , registering an annual growth of around 7-8\% during the forecast period (Future Market Insights 2014). Considering the Brazilian context, production is not enough to supply domestic demand, with imports of more than US \$ 3 million registered in stevioside in 2016 (Brasil 2017).

Considering the economic importance of the crop, studies have been carried out to define the most appropriate management practices to increase biomass yields and contents of compounds of interest (Jarma et al. 2010, Mandal et al. 2013, Moraes et al. 2013, Pal et al. 2013, 2015, Serfaty et al. 2013, Kumar et al. 2014a, Barbet-Massin et al. 2015). Among the different management practices for the crop, plant density and harvesting time seem to have a decisive influence on the production of both biomass and diterpene glycosides.

The main factor that affects the content of diterpene glycosides in stevia is flowering (Brandle and Rosa 1992). Radiation is also extremely important and it is considerably affected by planting densities, being determinant in the production of biomass and sweetening compounds (Serfaty et al. 2013).
The highest efficiency in the conversion of assimilates to the production of biomass in the species occurs at the beginning of flowering (LimaFilho 2004), the same stage in which highest levels of stevioside and rabaudioside A are observed, due to the greater expression of genes involved in the steviol glycosides biosynthetic pathway (Yang et al. 2015).

Regarding the influence of plant spacing, densities between 83000 and 111000 plants/ha are recommended for higher yields of biomass and sweetening compounds (Madan et al. 2010, Serfaty et al. 2013, Kumar et al. 2014a). Some authors report, however, that higher stands may still provide biomass increases by area (Kumar et al. 2014a).

The objective of this study was to evaluate the effect of different planting densities and harvesting times on the productive, physiological and phytochemical characteristics of stevia in Southern Brazil.

\section{MATERIALS AND METHODS}

\section{EXPERIMENTAL LOCATION, FIELD CONDITIONS AND GENERAL PROCEDURES}

The experiment was carried out under field conditions at the Cangüiri Experimental Station Center (CEEx), Federal University of Parana (UFPR), Pinhais, Parana, Brazil. The station is located at $25^{\circ} 23^{\prime} \mathrm{S}$ latitude, $49^{\circ} 07^{\prime} \mathrm{W}$ longitude and $920 \mathrm{~m}$ altitude.

The climate of the region is temperate humid with temperate summer, being classified as $\mathrm{Cfb}$ in the climatic classification system of Köppen (Köppen 1931). During the experiment, the global radiation registered by the National Institute of Meteorology (INMET) in Curitiba averaged $1007.18,1164.10,1386.56$ and $1179.82 \mathrm{~kJ} \mathrm{~m}^{-2}$ in November and December 2015, and January and February 2016, respectively. The average day lengths for these months were 13.3, 13.6, 13.4 
and 12.9 hours, according to latitude and solar declination. The maximum temperature recorded was $32.3^{\circ} \mathrm{C}$ and the minimum temperature was 11.6 ${ }^{\circ} \mathrm{C}$. The climatic data under which the experiment was conducted are shown in Table I. Soil samples were collected at a depth of $20 \mathrm{~cm}$ and sent for chemical and granulometric analysis, the results of analyses are presented in Table II.

The results of the soil analysis and recommendation of the Manual of fertilization and liming for the states of Rio Grande do Sul and Santa Catarina for stevia cultivation (Comissão de Química e Fertilidade do Solo 2004), were used to establish the necessity of nutrients supply. The application of $60 \mathrm{~kg} \mathrm{ha}^{-1}$ of nitrogen was proceeded. The application was made by sowing, using urea $(45 \%$ of $\mathrm{N})$ as a source of nitrogen. Also according to the recommendation of the manual, the application was parcelled out, being the first application of $1 / 3$ of the nitrogen at the time of planting and the remainder after 20 days.

The experiment was installed in November, 2015 , with plants of approximately $15 \mathrm{~cm}$ in height at different spacings according to treatments. After 15 days of the installation, the replanting was carried out, in order to maintain the planting densities without variations. A mortality rate of approximately $8 \%$ was observed, probably due to problems in plants adaptation when transferred from greenhouse to field conditions.

During the whole period of the experiment, weekly manual control of weeds were proceeded. No phytosanitary procedures were required to control pests and diseases. Irrigation was not necessary either.

TABLE I

Climatic conditions during the experiment. Pinhais, Parana, Brazil, 2015/2016.

\begin{tabular}{|c|c|c|c|c|}
\hline \multirow{2}{*}{ Variables } & \multicolumn{4}{|c|}{ Month/year } \\
\hline & NOV/2015 & DEC/2015 & JAN/2016 & FEB/2016 \\
\hline Precipitation $(\mathrm{mm})^{1}$ & 112.70 & 200.40 & 164.20 & 289.30 \\
\hline Relative humidity $(\%)^{1}$ & 90.98 & 88.57 & 86.35 & 89.46 \\
\hline Average Maximum Temperatures $\left({ }^{\circ} \mathrm{C}\right)^{1}$ & 24.47 & 26.46 & 26.06 & 27.78 \\
\hline Average Minimum Temperatures $\left({ }^{\circ} \mathrm{C}\right)^{1}$ & 15.61 & 17.48 & 16.67 & 18.16 \\
\hline Average temperature $\left({ }^{\circ} \mathrm{C}\right)^{1}$ & 18.81 & 20.91 & 20.42 & 21.55 \\
\hline Global radiation $\left(\mathrm{kJ} \mathrm{m}^{-2}\right)^{2}$ & 1007.18 & 1164.10 & 1386.56 & 1179.82 \\
\hline Day length $(h)^{3}$ & 13.3 & 13.6 & 13.4 & 12.9 \\
\hline
\end{tabular}

${ }^{1}$ Source: Paraná Meteorological System (SIMEPAR), 2016. ${ }^{2}$ Source: National Institute of Meteorology (INMET), 2017 (Data from the Municipality of Curitiba). ${ }^{3}$ Data calculated as a function of latitude and solar declination.

TABLE II

Chemical and granulometric characteristics of the soil used in the experiment. Pinhais, Parana, Brazil, $2015 / 2016$.

\begin{tabular}{|c|c|c|c|c|c|c|c|c|c|c|}
\hline \multicolumn{11}{|c|}{ Granulometry } \\
\hline Clay & \multicolumn{3}{|c|}{ Silt } & \multicolumn{2}{|r|}{ Total Sand } & \multicolumn{2}{|c|}{ Thick Sand } & \multicolumn{3}{|c|}{ Fine Sand } \\
\hline \multirow[b]{2}{*}{513} & \multicolumn{7}{|c|}{ 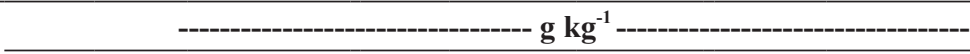 } & & & \\
\hline & \multicolumn{3}{|c|}{175} & \multicolumn{2}{|c|}{313} & \multicolumn{2}{|c|}{141} & \multicolumn{3}{|c|}{172} \\
\hline \multicolumn{11}{|c|}{ Chemical Characteristics } \\
\hline $\mathrm{pH}$ & & $\mathrm{Al}^{+3}$ & $\mathrm{H}^{+}+\mathrm{Al}^{+3}$ & $\mathrm{Ca}^{+2}$ & $\mathrm{Mg}^{+2}$ & SB & $\mathrm{T}$ & $\mathrm{P}$ & $\mathrm{C}$ & $\mathrm{V}$ \\
\hline $\mathrm{CaCl}_{2}$ & SMP & & -------- & 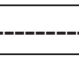 & $\mathrm{cmol}_{\mathrm{c}} \mathrm{dm}^{-3}-\cdots$ & 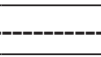 & & $\mathrm{mg} \mathrm{dm}^{-3}$ & $\mathrm{~g} \mathrm{dm}^{-3}$ & $\%$ \\
\hline 6.0 & 6.3 & 0.0 & 4.00 & 6.50 & 2.90 & 10.05 & 14.05 & 46.20 & 28.9 & 72 \\
\hline
\end{tabular}




\section{PLANT MATERIAL AND PLANTLETS PRODUCTION}

A total of seven accessions of $S$. rebaudiana, identified by the numbers $4,6,7,8,9,12$ and 14 were provided by Brazilian Company of Agricultural Research (EMBRAPA) and evaluated by Francisco et al. (2018) regarding productive performance in the edaphoclimatic conditions of the metropolitan region of Curitiba, state of Paraná.

Accessions 6, 7 and 14, were identified with rebaudioside $\mathrm{A} /$ stevioside ratio close to 1 , desirable for the industry. The accession 6 , selected for use in the present study, yielded a dry mass of leaves of $4008.3 \mathrm{~kg} \mathrm{ha}^{-1}$, in two harvests, with rebaudioside A/ stevioside ratio of 0.95 , and yield of $9.7 \%$ of Rebaudioside A in the average of the two harvests (Francisco et al. 2018).

The plant material was multiplied in vitro by nodal segments, according to protocol reported by Das et al. (2011). Plantlets with two pairs of leaves were transferred to $120 \mathrm{~cm}^{3}$ plastic tubes filled with Tropstrato ${ }^{\circledR}$ commercial substrate. The tubes were placed in plastic supports and remained for 15 days for acclimatization in a greenhouse with intermittent mist of 5 seconds every 30 minutes. After this period the tubes with plants were transferred to greenhouse without mist, with daily manual watering for a period of 30 days. At the end of the period, the plantlets with $15 \mathrm{~cm}$ height and five pairs of leaves were selected for the field experiment.

\section{EXPERIMENTAL DESIGN}

The experimental design was in randomized blocks with a split-plot scheme, evaluating the effect of three planting densities (166 667, 83333 and 33333 plants $\mathrm{ha}^{-1}$ ) in the plots and three harvesting periods (before, at the beginning and at full flowering) in the subplots, with 4 replicates. Each plot contained 65 plants, being used nine plants in each subplot.

The plant densities were calculated as a function of different spacings: $0.60 \times 0.50 \mathrm{~m}$;
$0.40 \times 0.30 \mathrm{~m}$; and $0.30 \times 0.20 \mathrm{~m}$, between lines and plants, respectively. Harvesting times were performed according to plant phenology. The before flowering harvest took place 75 days after transplanting, when less than one half of the plants showed flower bud formation, and with no open flower. Harvesting at the beginning of flowering was carried out when the plants had about $5 \%$ of capitula with the presence of open flowers, which occurred 96 days after transplanting. The full flowering harvest occurred when more than 50\% of the plants had most of the capitula with open flowers, on the 110th day after transplanting.

\section{BIOMETRIC EVALUATIONS AND CALCULATION OF PHYSIOLOGICAL INDEXES}

The plants were harvested by cutting stems at $5 \mathrm{~cm}$ from the soil. After this procedure the leaves were separated from the branches and flowers manually, weighed for determination of fresh mass of leaves and branches, and then stored in $\mathrm{Kraft} \AA$ multifoil paper bags. The stems and leaves remained in dryer with forced air circulation at $65^{\circ} \mathrm{C}$ until constant weight and were again weighed to determine the dry mass of leaves and total dry mass of the aerial part.

A total of 60 discs of $0.785 \mathrm{~cm}^{2}$ of leaves were weighted from each experimental subplot for the measurement of leaf area (LA) calculated in proportion to the total weight of leaves. Leaf area index (LAI), specific leaf area (SLA), leaf area ratio (LAR) and leaf mass ratio (LMR) were calculated.

Leaf area index was determined by the ratio between leaf area and soil area (SA) occupied by the plants obtained in each subplot: IAF $=\mathrm{LA} / \mathrm{SA}$. LAR was calculated by the ratio between total leaf area and total dry mass (TDM): RAF $=\mathrm{LA} / \mathrm{TDM}$. SLA was calculated by the ratio between leaf area and leaf dry mass (LDM): SLA = LA / LDM. LMR was calculated by the ratio between dry leaf mass and total dry mass: RPF $=$ LDM / TDM. 


\section{BIOCHEMICAL EVALUATIONS}

To determine the levels of $a, b$ and total chlorophylls, twenty disks of $0.785 \mathrm{~cm}^{2}$ of the central region of leaf tissues were removed and weighed. It was macerated in a mortar with $10 \mathrm{ml}$ of $80 \%$ acetone and placed in test tubes, which were centrifuged for 10 minutes at $12000 \mathrm{rpm}$ with refrigeration at $4^{\circ} \mathrm{C} .1 \mathrm{ml}$ of the supernatant was transferred to cuvettes and subjected to spectrophotometer (UV1601-Shimadzu, Kyoto, Japan) readings at the wavelengths of 645 and $663 \mathrm{~nm}$ using $80 \%$ acetone as a control. For the quantification of chlorophylls, the equations described by Arnon (1949) were used.

Total protein content was determined by Bradford (1976) method. An amount of $0.5 \mathrm{~g}$ of fresh leaf tissue from each sample was macerated in a mortar with $10 \mathrm{ml}$ of $0.2 \mathrm{M}$ phosphate buffer (pH 7.5) and filtered. An aliquot of $0.05 \mathrm{ml}$ of the filtrate was placed in a test tube along with 0.45 $\mathrm{ml}$ of distilled water and $1.0 \mathrm{ml}$ of the Bio-Rad $\AA$

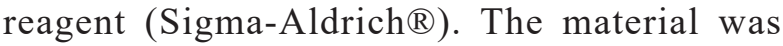
transferred to quartz cuvettes and subjected to spectrophotometer reading at $630 \mathrm{~nm}$, with bovine serum albumin as control.

Total sugar contents were determined by the phenol-sulfuric method, described by Dubois et al. (1956). The amount of $0.1 \mathrm{~g}$ of fresh leaf tissue was macerated in a mortar containing $10 \mathrm{ml}$ of $0.2 \mathrm{M}$ phosphate buffer ( $\mathrm{pH} 7.5$ ) and filtered. $0.01 \mathrm{ml}$ of the filtrate was placed in the test tube with 0.049 $\mathrm{ml}$ of distilled water. In this solution it was added $0.5 \mathrm{ml}$ of $5 \%$ Phenol and $2.5 \mathrm{ml}$ of concentrated sulfuric acid. After cooling to room temperature the material was transferred to quartz cuvettes and subjected to spectrophotometer reading, at $490 \mathrm{~nm}$. The concentration of total sugars was determined by standard glucose curve.

The analyses of stevioside and rebaudioside A levels were performed according to methodology adapted from Kolb et al. (2001). For the extraction of the diterpene glycosides $0.5 \mathrm{~g}$ of dry leaf tissue was crushed and transferred to containers containing $50 \mathrm{ml}$ of $70 \%$ ethanol. The solution was subjected to constant stirring for 30 minutes in a water bath at $70^{\circ} \mathrm{C}$. The material was filtered through nylon syringe filters (porous $0.2 \mu \mathrm{m}$ ), transferred to Eppendorf tubes and stored in a freezer $\left(-18^{\circ} \mathrm{C}\right)$ until quantification.

The extract was injected into HPLC (High performance liquid chromatography) apparatus (SPD-10A, CTO-10A, CBM-10A and LC-10 Shimadzu $\left.{ }^{\circledR}\right)$, NH 2 column ( $\left.250 \times 4.6 \mathrm{~mm}\right)$, mobile phase composed of acetonitrile and ultrafiltered water (80:20), flow of $2 \mathrm{ml} / \mathrm{min}$, temperature of $30^{\circ} \mathrm{C}$ and detection with $\mathrm{UV}$ reader at $210 \mathrm{~nm}(0.04$ AUFS).

The quantification was made through a calibration curve created by dilution of stevioside and rebaudioside A analytical standards, trade mark Sigma-Aldrich ${ }^{\circledR}$. The levels of stevioside and rebaudioside $\mathrm{A}\left(\mathrm{mg} \mathrm{g}^{-1}\right)$, ratio between rebaudioside A and stevioside (R/E), and yields of stevioside and rebaudioside $\mathrm{A}$ were determined.

\section{STATISTICAL ANALYSES}

Data were submitted to the Bartlett test to verify homogeneity of variances and, when homogeneous, ANOVA variance analysis was performed. When significant, the means were compared by Tukey's test at 1 and 5\% probability, using the statistical software ASSISTAT ${ }^{\circledR}$ (Silva and Azevedo 2016).

\section{RESULTS}

For the variables height, number of branches, LAI, SLA, LMR and LAR there was no interaction between planting densities and harvest period. Evaluating the factors isolated, planting density was only significant for the LAI $(p>0,005)$ while the harvesting time did not show significance only for the LMR. LMR ranged from 0.48 to 0.56 (Table III) and was not affected by the evaluated cultivation conditions. 
The height of plants reached maximum values in the full flowering harvest, with an average increment of more than 15 centimetres compared to the harvest before flowering. The number of branches was also significantly lower $(p<0,001)$ in the harvest before flowering compared to the other periods. The same was observed for LAI, SLA and LAR, with higher means on harvests on the beginning and at full flowering. For the LAI, although, the plant density was the factor that presented greater influence. The highest indexes (average 1.45) were observed in the highest plant density, whereas the lowest values were found in the density of 33333 plants ha ${ }^{-1}(0.59)$.

Regarding variables related to biomass accumulation, there was interaction between plant densities and harvesting times for aerial part dry mass yield. Evaluating the factors in isolation, both harvesting times and planting densities were significant for dry mass of leaves per plant, dry mass of aerial part per plant and leaves dry mass of leaves yield.
Considering harvesting times, dry mass of leaves per plant, dry mass of aerial part per plant and leaves dry mass of yield presented similar behavior, with superiority in the beginning and full flowering harvests. The lower planting density (33 333 plants $\mathrm{ha}^{-1}$ ) resulted in higher accumulation of leaf biomass and total biomass per plant, but the number of plants at the highest density (166 667 plants $\mathrm{ha}^{-1}$ ) compensated for the lower production per unit, providing the highest leaf dry matter yields (Table IV).

For aerial part dry mass yield, it was observed an interaction effect $(p \leq 0,005)$ between harvesting time and plant density. It was noticed that in the pre-flowering harvest there was no effect of planting densities. At the beginning of flowering, the densities of 166667 and 83333 plants ha ${ }^{-1}$ promoted greater accumulations of biomass per area. At the harvest in full flowering, the density of 166667 plants ha ${ }^{-1}$ was superior to the other densities (Table V).

TABLE III

Average height, number of branches, leaf area index (LAI), specific leaf area (SLA), leaf mass ratio (LMR) and leaf area ratio (LAR) in Stevia rebaudiana grown at different planting densities and harvesting times (Pinhais, Parana, Brazil, 2016).

\begin{tabular}{|c|c|c|c|c|c|}
\hline \multirow{7}{*}{ 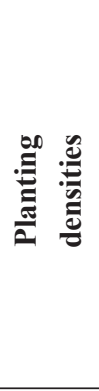 } & Variable & $\begin{array}{c}166667 \\
\text { plants ha }\end{array}$ & $\begin{array}{c}83333 \\
\text { plants ha }{ }^{-1}\end{array}$ & $\begin{array}{c}33333 \\
\text { plants ha } \\
\end{array}$ & LSD \\
\hline & Height $(\mathrm{cm})$ & $54.05^{\mathrm{ns}}$ & 57.97 & 55.79 & 7.43 \\
\hline & Number of branches & $14.66^{\mathrm{ns}}$ & 18.77 & 18.28 & 6.46 \\
\hline & Leaf area index & $1.45 \mathrm{a}$ & $1.05 \mathrm{~b}$ & $0.59 \mathrm{c}$ & 0.39 \\
\hline & Specific leaf area $\left(\mathrm{cm}^{2} \mathrm{~g}^{-1}\right)$ & $24.75^{\mathrm{ns}}$ & 19.61 & 24.71 & 8.29 \\
\hline & Leaf mass ratio $\left(\mathrm{g} \mathrm{g}^{-1}\right)$ & $0.50^{\mathrm{ns}}$ & 0.51 & 0.55 & 0.04 \\
\hline & Leaf area ratio $\left(\mathrm{cm}^{2} \mathrm{~g}^{-1}\right)$ & $13.71^{\mathrm{ns}}$ & 11.18 & 14.54 & 4.54 \\
\hline \multirow{7}{*}{$\underbrace{\infty}_{0}$} & Variable & $\begin{array}{c}\text { Before } \\
\text { flowering }\end{array}$ & $\begin{array}{l}\text { Onset of } \\
\text { flowering }\end{array}$ & $\begin{array}{c}\text { Full } \\
\text { flowering }\end{array}$ & \\
\hline & Height $(\mathrm{cm})$ & $44.54 \mathrm{~b}$ & $61.41 \mathrm{a}$ & $61.85 \mathrm{a}$ & 2.54 \\
\hline & Number of branches & $9.74 \mathrm{~b}$ & $20.96 \mathrm{a}$ & $21.05 \mathrm{a}$ & 2.60 \\
\hline & Leaf area index & $0.62 \mathrm{~b}$ & $1.32 \mathrm{a}$ & $1.15 \mathrm{a}$ & 0.36 \\
\hline & Specific leaf area $\left(\mathrm{cm}^{2} \mathrm{~g}^{-1}\right)$ & $14.63 \mathrm{~b}$ & $28.61 \mathrm{a}$ & $25.82 \mathrm{a}$ & 10.02 \\
\hline & Leaf mass ratio $\left(\mathrm{g} \mathrm{g}^{-1}\right)$ & $0.56^{\mathrm{ns}}$ & 0.48 & 0.51 & 0.01 \\
\hline & Leaf area ratio $\left(\mathrm{cm}^{2} \mathrm{~g}^{-1}\right)$ & $8.33 \mathrm{~b}$ & $16.40 \mathrm{a}$ & $14.70 \mathrm{a}$ & 5.76 \\
\hline
\end{tabular}

Means followed by the same letter in the rows do not differ from each other by the Tukey's test at 5\% probability. LSD: Least significant difference. ${ }^{\mathrm{ns}}$ non-significant. 
There was no significant interaction between treatments for total chlorophyll, chlorophyll $a$ and $b$, proteins and total sugars. Evaluating the factors isolated, planting density influenced only the production of chlorophyll $a$ and total chlorophyll, while harvesting time was significant for protein and total soluble sugars. Chlorophyll $a$ and total chlorophyll content were significantly higher at planting densities of 33333 and 88333 plants ha ${ }^{-1}$.

The protein contents in stevia leaves varied between 44.59 and $62.09 \mathrm{mg} \mathrm{g}^{-1}$, with higher level at the before flowering harvest when compared to harvests at the beginning and full flowering. A similar pattern was observed for sugar contents with an average of $462.81 \mathrm{mg} \mathrm{g}^{-1}$ in leaves harvested before plant flowering (Table VI).

For stevioside and rebaudioside A contents, rebaudioside $\mathrm{A} /$ stevioside ratio and rebaudioside A yield there was interaction between plant densities and harvesting times. Only for stevioside yield there was no interaction. For this variable, although, there was effect of plant densities and harvesting times as isolated factors.

The interaction between harvest at the beginning of flowering and the adoption of planting density of 33333 plants ha ${ }^{-1}$ promoted the highest contents of stevioside and rebaudioside $\mathrm{A}$.
The highest rebaudioside $\mathrm{A} /$ stevioside ratio was obtained when the plants in densities of 33333 and 166667 plants ha ${ }^{-1}$ were harvest at the beginning of flowering. In relation to the productivity of the compounds, greater yield of stevioside was observed in the beginning and full flowering harvests. Regarding planting densities, the stand of 166667 plants ha ${ }^{-1}$ promoted higher yields, due to the greater accumulation of biomass per area. For rabaudioside A productivities, interaction between treatments was observed, and the harvest at the beginning of flowering at the highest planting density reached higher values $\left(43.22 \mathrm{~kg} \mathrm{ha}^{-1}\right)$ (Table VII).

The yields of steviol glycosides (stevioside + rebaudioside A) obtained at the beginning of flowering and density of 166667 plants ha ${ }^{-1}$ reached $116.43 \mathrm{~kg} \mathrm{ha}^{-1}$, with a rebaudioside $\mathrm{A} /$ stevioside ratio of 0.60 .

\section{DISCUSSION}

There was an evident increase in plant vegetative development from the harvest before flowering, mainly characterized by plant height, branches number, leaf area and dry mass. The increase in the branches number at harvests in full and at the beginning of flowering can be attributed to the

TABLE IV

Average dry mass of leaves and aerial part per plant and leaves dry mass yield in Stevia rebaudiana grown at different planting densities and harvesting times. (Pinhais,Parana, Brazil, 2016).

\begin{tabular}{|c|c|c|c|c|c|}
\hline \multirow{4}{*}{ 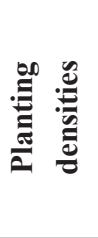 } & Variable & $\begin{array}{c}166667 \\
\text { plants ha }^{-1}\end{array}$ & $\begin{array}{c}83333 \\
\text { plants ha }^{-1}\end{array}$ & $\begin{array}{c}33333 \\
\text { plants ha }^{-1}\end{array}$ & LSD \\
\hline & Dry mass of leaves (g plant ${ }^{-1}$ ) & $6.32 \mathrm{~b}$ & $10.65 \mathrm{ab}$ & $14.30 \mathrm{a}$ & 5.64 \\
\hline & Dry mass of aerial part (g plant $\left.{ }^{-1}\right)$ & $12.69 \mathrm{~b}$ & $21.22 \mathrm{ab}$ & $26.31 \mathrm{a}$ & 10.82 \\
\hline & Leaves dry mass yield $\left(\mathrm{kg} \mathrm{ha}^{-1}\right)$ & $1053.67 \mathrm{a}$ & $887.40 \mathrm{ab}$ & $476.83 \mathrm{~b}$ & 534.12 \\
\hline \multirow{4}{*}{ 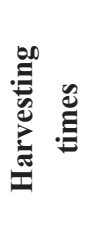 } & Variable & $\begin{array}{c}\text { Before } \\
\text { flowering }\end{array}$ & $\begin{array}{l}\text { Onset of } \\
\text { flowering }\end{array}$ & $\begin{array}{c}\text { Full } \\
\text { flowering }\end{array}$ & \\
\hline & Dry mass of leaves $\left(\mathrm{g}_{\mathrm{plant}} \mathrm{p}^{-1}\right)$ & $5.46 \mathrm{~b}$ & $11.63 \mathrm{a}$ & $14.18 \mathrm{a}$ & 4.94 \\
\hline & Dry mass of aerial part (g plant $\left.{ }^{-1}\right)$ & $9.69 \mathrm{~b}$ & $24.07 \mathrm{a}$ & $26.31 \mathrm{a}$ & 6.15 \\
\hline & Leaves dry mass yield $\left(\mathrm{kg} \mathrm{ha}^{-1}\right)$ & $433.40 \mathrm{~b}$ & $943.82 \mathrm{a}$ & $1040.67 \mathrm{a}$ & 334.02 \\
\hline
\end{tabular}

Means followed by the same letter in the rows do not differ from each other by the Tukey's test at 5\% probability. LSD: Least significant difference. ${ }^{\text {ns }}$ non-significant. 
TABLE V

Interaction values of aerial part dry mass yield in Stevia rebaudiana grown at different plant densities and harvesting times. (Pinhais, Parana, Brazil, 2016).

\begin{tabular}{lcccc}
\hline \multirow{2}{*}{ Harvesting time } & \multicolumn{3}{c}{ Planting densities (plants ha $\left.{ }^{-1}\right)$} \\
\cline { 2 - 4 } Before flowering & $\mathbf{1 6 6 \mathbf { 6 6 7 }}$ & $\mathbf{8 3 ~ 3 3 3}$ & $\mathbf{3 3 ~ 3 3 3}$ & Mean \\
Onset of flowering & $1061.55 \mathrm{bA}$ & $870.80 \mathrm{bA}$ & $408.22 \mathrm{bA}$ & 780.19 \\
Full flowering & $1985.01 \mathrm{aA}$ & $2213.87 \mathrm{aA}$ & $984.24 \mathrm{abB}$ & 1737.63 \\
Mean & $2596.49 \mathrm{aA}$ & $1549.52 \mathrm{aB}$ & $1223.51 \mathrm{aB}$ & 1789.84 \\
\hline
\end{tabular}

LSD for columns 665.63; LSD for rows 855.94. Significant interaction $(P=0.0193)$

Means followed by lowercase letters in the columns and capital letters in the rows do not differ from each other by the Tukey's test at $5 \%$ probability. LSD: Least significant difference. ${ }^{\text {ns }}$ non-significant. LSD: Least significant difference.

TABLE VI

Average contents of chlorophyll a, chlorophyll b, total chlorophyll, proteins and sugars in Stevia rebaudiana grown at different plant densities and harvesting times (Pinhais, Parana, Brazil, 2016).

\begin{tabular}{|c|c|c|c|c|c|}
\hline \multirow{6}{*}{ 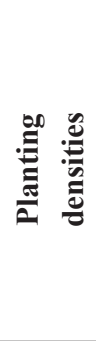 } & Variable & $\begin{array}{c}166667 \\
\text { plants ha }\end{array}$ & $\begin{array}{c}83333 \\
\text { plants ha } \\
\end{array}$ & $\begin{array}{c}33333 \\
\text { plants ha } \\
\end{array}$ & LSD \\
\hline & Chlorophyll $a\left(\mathrm{mg} / \mathrm{cm}^{2}\right)$ & $0.065 \mathrm{~b}$ & $0.080 \mathrm{a}$ & $0.078 \mathrm{a}$ & 0.007 \\
\hline & Chlorophyll $b\left(\mathrm{mg} / \mathrm{cm}^{2}\right)$ & $0.035^{\mathrm{ns}}$ & 0.041 & 0.036 & 0.009 \\
\hline & Total Chlorophyll $\left(\mathrm{mg} / \mathrm{cm}^{2}\right)$ & $0.100 \mathrm{~b}$ & $0.121 \mathrm{a}$ & $0.115 \mathrm{a}$ & 0.014 \\
\hline & Proteins $(\mathrm{mg} / \mathrm{g})$ & $49.03^{\mathrm{ns}}$ & 49.59 & 53.20 & 13.41 \\
\hline & Sugars (mg/g) & $422.30^{\text {ns }}$ & 382.47 & 467.62 & 105.37 \\
\hline \multirow{6}{*}{ 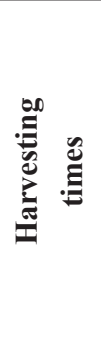 } & Variable & Before flowering & $\begin{array}{l}\text { Onset of } \\
\text { flowering }\end{array}$ & $\begin{array}{c}\text { Full } \\
\text { flowering }\end{array}$ & \\
\hline & Chlorophyll $a\left(\mathrm{mg} / \mathrm{cm}^{2}\right)$ & $0.068^{\mathrm{ns}}$ & 0.074 & 0.081 & 0.017 \\
\hline & Chlorophyll $b\left(\mathrm{mg} / \mathrm{cm}^{2}\right)$ & $0.036^{\mathrm{ns}}$ & 0.037 & 0.039 & 0.009 \\
\hline & Total Chlorophyll $\left(\mathrm{mg} / \mathrm{cm}^{2}\right)$ & $0.105^{\mathrm{ns}}$ & 0.111 & 0.120 & 0.025 \\
\hline & Proteins $(\mathrm{mg} / \mathrm{g})$ & $62.09 \mathrm{a}$ & $44.59 \mathrm{~b}$ & $45.14 \mathrm{~b}$ & 11.96 \\
\hline & Sugars (mg/g) & $462.81 \mathrm{a}$ & $428.85 \mathrm{ab}$ & $369.72 \mathrm{~b}$ & 76.31 \\
\hline
\end{tabular}

Means followed by the same letter in the rows do not differ from each other by the Tukey's test at 5\% probability. LSD: Least significant difference. ${ }^{\text {ns }}$ non-significant.

longer time for the shoots and roots development. Since the synthesis of cytokinins occurs mainly at the root / radicular apices, a more developed root system allows a greater production of these phytohormones and their export to the stems, where they stimulate the production of lateral branches (Pal et al. 2015). In a study carried out with different harvesting regimes for stevia, Pal et al. (2015) also verified the influence of plant life cycle on the number of branches and pointed out a positive relation of this variable with the leaf area index. Similar behaviour was observed in the present study, with an average increase of more than two fold in the LAI when the harvest occurs at the beginning of flowering compared to the before flowering.

In spite of the difference observed during the crop cycle in relation to the harvesting times, the spacing was the factor that had the greatest influence on LAI, that increased with higher planting density, as observed by $S$. rebaudiana grown in Colombia (Jarma et al. 2010) and in the Himalayas (Kumar et al. 2014b). Kumar et al. (2014b) report maximum LAI of 1.21 in spacing of $30 \times 30 \mathrm{~cm}$ and minimum 
TABLE VII

Averages of stevioside and rebaudioside A contents, rebaudioside $\mathbf{A}$ /stevioside ratio and stevioside and rebaudioside $\mathrm{A}$ yields in Stevia rebaudiana grown at different plant densities and harvesting times (Pinhais, Parana, Brazil, 2016).

\begin{tabular}{|c|c|c|c|c|}
\hline \multirow{3}{*}{ Harvesting time } & \multicolumn{3}{|c|}{ Plant densities (plants ha $\mathbf{h}^{-1}$ ) } & \multirow[b]{3}{*}{ Mean } \\
\hline & \multicolumn{3}{|c|}{ Stevioside content $\left(\mathrm{mg} \mathrm{g}^{-1}\right)$} & \\
\hline & 166667 & 83333 & 33333 & \\
\hline Before Flowering & $71.02 \mathrm{aA}$ & $62.36 \mathrm{aA}$ & $67.81 \mathrm{bA}$ & 67.06 \\
\hline Onset of Flowering & $56.76 \mathrm{bB}$ & $48.52 \mathrm{bB}$ & $86.98 \mathrm{aA}$ & 64.08 \\
\hline Full Flowering & $43.51 \mathrm{cA}$ & $46.29 \mathrm{bA}$ & $55.48 \mathrm{bA}$ & 48.42 \\
\hline Mean & 57.09 & 52.39 & 70.09 & \\
\hline \multicolumn{5}{|c|}{ LSD for columns 12.98 ; LSD for rows 13.44. Significant interaction $(P=0.0004)$} \\
\hline \multicolumn{5}{|c|}{ Rebaudioside A content $\left(\mathrm{mg} \mathrm{g}^{-1}\right)$} \\
\hline Before Flowering & $26.34 \mathrm{aA}$ & $24.82 \mathrm{aA}$ & $30.19 \mathrm{bA}$ & 27.11 \\
\hline Onset of Flowering & $33.60 \mathrm{bB}$ & $22.56 \mathrm{bB}$ & $47.31 \mathrm{aA}$ & 34.48 \\
\hline Full Flowering & $17.65 \mathrm{cA}$ & $20.99 \mathrm{bA}$ & $30.06 \mathrm{bA}$ & 22.90 \\
\hline Mean & 25.86 & 22.80 & 35.86 & \\
\hline \multicolumn{5}{|c|}{ LSD for columns 8.45; LSD for rows 9.08. Significant interaction $(P=0.0037)$} \\
\hline \multicolumn{5}{|c|}{ Rebaudioside $\mathrm{A} /$ stevioside ratio } \\
\hline Before Flowering & $0.37 \mathrm{bB}$ & $0.40 \mathrm{bAB}$ & $0.45 \mathrm{bA}$ & 0.40 \\
\hline Onset of Flowering & $0.60 \mathrm{aA}$ & $0.47 \mathrm{aB}$ & $0.54 \mathrm{aA}$ & 0.53 \\
\hline Full Flowering & $0.41 \mathrm{bB}$ & $0.45 \mathrm{abB}$ & $0.54 \mathrm{aA}$ & 0.46 \\
\hline Mean & 0.46 & 0.43 & 0.51 & \\
\hline \multicolumn{5}{|c|}{ LSD for columns 0.06 ; LSD for rows 0.07 . Significant interaction $(P=0.0002)$} \\
\hline \multicolumn{5}{|c|}{ Stevioside yield $\left(\mathrm{kg} \mathrm{ha}^{-1}\right)$} \\
\hline Before Flowering & 40.76 & 30.46 & 15.97 & $29.06 \mathrm{~b}$ \\
\hline Onset of Flowering & 73.21 & 51.94 & 39.65 & $54.94 \mathrm{a}$ \\
\hline Full Flowering & 54.60 & 50.47 & 39.89 & $48.32 \mathrm{a}$ \\
\hline Mean & $56.19 \mathrm{~A}$ & $44.29 \mathrm{~B}$ & $31.84 \mathrm{C}$ & \\
\hline \multicolumn{5}{|c|}{ LSD for columns 9.42; LSD for rows 10.35 . Non-significant interaction $(P=0.3713)$} \\
\hline \multicolumn{5}{|c|}{ Rebaudioside A yield $\left(\mathrm{kg} \mathrm{ha}^{-1}\right)$} \\
\hline Before Flowering & $15.14 \mathrm{bA}$ & $11.91 \mathrm{bA}$ & $7.05 \mathrm{bA}$ & 11.36 \\
\hline Onset of Flowering & $43.22 \mathrm{aA}$ & $24.20 \mathrm{aB}$ & $21.35 \mathrm{aB}$ & 29.59 \\
\hline Full Flowering & $22.68 \mathrm{bA}$ & $23.70 \mathrm{aA}$ & $21.68 \mathrm{aA}$ & 22.69 \\
\hline Mean & 27.02 & 19.93 & 16.69 & \\
\hline
\end{tabular}

Means followed by lowercase letters in the columns and capital letters in the rows do not differ from each other by the Tukey's test at 5\% probability. LSD: Least significant difference. ${ }^{\text {ns }}$ non-significant. LSD: Least significant difference.

of 0.48 in spacing $0.45 \times 0.30 \mathrm{~cm}$, values similar to the present work. Lima-Filho (2004) in analysis of crop growth reported LAI of 0.35 , considered very low. Jarma et al. (2010) reported a maximum value of 3.15, according to the authors, still far from the critical LAI estimated for the crop. These variations indicate the importance of using other indicators to understand the vegetative development of the plant.

SLA considerably increased in the beginning and full flowering harvests in comparison to the pre-flowering harvest. This fact can be attributed to the greater development of plants and leaf area 
expansion that promotes greater shading, and consequently, reduction of radiation along the canopy. Under low radiation conditions, the plants increase the leaf expansion and, consequently, SLA. In general, these changes results in increase the interception of radiation, rising the photosynthetic efficiency (Lambers et al. 2008). Considering that no alterations were observed in LMR, the values for LAR had a similar behaviour compared to SLA, as an adaptation to lower levels of radiation through the canopy with the increase of vegetative development in plants harvested at beginning and full flowering. Similar pattern was reported by Jarma et al. (2006) for $S$. rebaudiana cultivated in the Colombia, where an increase in LAR was observed as the incident radiation decreased.

The increase in leaf and aerial part dry mass and leaf yield on beginning and full flowering as a function of greater plant development was also reported by Lima-Filho (2004) when performing analysis of stevia growth in Brazil. For stevia grown in Israel, the interaction between planting densities and three harvest indicators showed that flowering is actually the most appropriate parameter to indicate the harvest period of the species. The best results for leaf biomass were obtained at the start of flowering (Serfaty et al. 2013). Regarding planting densities, the authors reported that a stand of $100000 \mathrm{ha}^{-1}$ plants resulted in higher yields of leaf biomass $\left(3000 \mathrm{~kg} \mathrm{ha}^{-1}\right)$.

This value is similar to those recommended by Donalisio et al. (1982). Increases in biomass values were also reported by Madan et al. (2010) with densities between 83000 and 111000 plants $\mathrm{ha}^{-1}$. The authors, however, have not evaluated higher planting densities, as in the present work. In spite of lower leaf mass yields than those observed by the authors, in this study, the cultivation with 166667 plants $^{-1} \mathrm{a}^{-1}$ presented higher yields than the lower densities. However, an increase of more than 5-fold in planting density resulted in increase of two times in productivity. In field conditions where seedlings or seeds are not a limiting factor, increase the density could be considered not only to improve productivity but also as a strategy for the cultural control of weeds (Basuki 1990, Taleie et al. 2012, Kumar et al. 2014b)

Higher production of biomass per plant in the lower density can be associated with more radiation and soil resources (Jarma et al. 2006, Kumar et al. 2012, 2014a). Higher yields in high densities are a function of the greater number of plants per area, which compensates the great biomass production per plant (Kumar et al. 2014a).

The highest planting density promoted an average leaf yield of $1053.67 \mathrm{~kg} \mathrm{ha}^{-1}$. This value is close to the maximum reported by Pal et al. (2013, 2015), Kumar et al. (2014b), González et al. (2007) and Mejegi et al. (2005) for the first cut in the first year of cultivation.

Yield values obtained in the present work, notwithstanding, are lower than those reported by Francisco et al. (2018) for the same genetic material under similar cultivation conditions on a density of 80000 plants ha ${ }^{-1}$, with planting carried out in September 2014, when it was reported a dry leaf yield of $3255.1 \mathrm{~kg} \mathrm{ha}^{-1}$. This reduction in productivity may be associated with a decrease of 48 days in the vegetative period caused by differences in the transplant period, which occurred in November in the present experiment.

The late planting (November) reduces the period of vegetative growth, since, as at the end of December there is a constant photoperiod decrease, which stimulates the flowering of the crop, that occurs usually between January and March in the southern hemisphere (Ahmed et al. 2011, Yadav et al. 2011). In Brazil, stevia planting made until mid-October are recommended to increasing the duration of the growing season, when plants reach the maximum economic yields (Lima-Filho 2004, Lima-Filho et al. 2004).

Regarding to photosynthetic pigments, it was observed an increase in chlorophyll $a$ and 
total chlorophyll higher values were observed in lower plant densities. Shaded leaves minimize light limitation through increases in light capture capacity and decrease in the carboxylation capacity and mesophyll conductance, but this does not invariably lead to higher concentrations of chlorophyll per unit area of leaf. In most plant species, higher levels of chlorophyll per unit of fresh mass and per chloroplast in shaded leaves are compensated by the lower number of chloroplasts and a lower fresh mass per area (Lambers et al. 2008). This fact results in a practically constant level of chlorophyll per area unit or even in higher levels of chlorophyll per leaf area in leaves submitted to lower shading, as observed in the present study at lower planting densities. Similar behaviour was observed in Myrtus communis L., where higher concentrations of chlorophyll per unit of leaf area was found in leaves grown in full sun (Mendes et al. 2001).

Although there is not always a positive correlation between chlorophyll content and liquid photosynthesis it is common for a plant with higher chlorophyll content to reach higher photosynthetic rates, due to its higher potential to capture photons per unit of time (Porra et al. 1989, Chappelle and Kim 1992, Rêgo and Possamai 2004). In stevia, Wu et al. (2013) reported that increases in chlorophyll $a$ levels increase the solar energy capture capacity and may consist of a method to increase net photosynthesis in the species.

Higher levels of chlorophyll were positively related to accumulation of biomass and biosynthesis of enzymes associated to electrons transport, proteins and carbohydrates in plants of $S$. rebaudiana (Jain et al. 2009), reinforcing the idea of greater photosynthetic activities when there is a higher content of chlorophylls by leaf area. In the present work it was also observed that the highest values of chlorophyll $a$ and total chlorophyll in the lowest planting densities are related to the higher biomass productions per plant.
In addition to the increase in biomass, it is worth mentioning that a relationship between the accumulation of steviol glycosides, both in vivo and in vitro, is also described with the extension of the development of the chloroplast membrane system and the content of photosynthetic pigments (Ladygin et al. 2008, Wu et al. 2013). According to Jain et al. (2009), the relationship between the activity of the photosynthetic apparatus and the production of diterpene glycosides suggests that the synthesis of isoprenoids in chloroplasts is a determining factor for the production of the sweetening substances. The biosynthesis of steviol glycosides and chlorophyll comes from the same precursors, isopentenyl diphosphate and dimethylallyl diphosphate of the methylerythritol phosphate pathway in plastids (Guleria et al. 2014). Thus, the ideal conditions for the production of chlorophyll molecules at the beginning of the biosynthetic pathway are the same as those regulating the production of the sweetening substances in stevia.

Considering the relationship between higher chlorophyll content and higher biosynthetic activity, it is possible to associate the production of steviol glycosides with the greater availability of carbohydrates from photosynthesis since the precursor molecules for the MEP pathway (glyceraldehyde-3-phosphate and pyruvate) derive directly from photosynthesis or glycolysis (BarbetMassin et al. 2015).

Proteins and sugars are also important molecules in stevia metabolism. For both it was observed a similar pattern regarding plant flowering, with higher contents before flowering following constant decrease after that. The reduction of protein levels occurs due to redistribution of nitrogenous compounds from leaves to reproductive organs throughout the plant cycle (Reis et al. 2009, Xu et al. 2012). During vegetative growth, nitrogen is rapidly absorbed by the roots and transported to the leaves. In leaves, nitrate reduction produces amino acids that are incorporated into leaf protein 
(Masclaux-Daubresse et al. 2010). During flowering remobilization of leaf nitrogen protein occurs and amino acids translocation to the reproductive organs is high, decreasing the contents of these compounds in the leaf (Imsande and Touraine 1994, Bredemeier and Mundstock 2000). This remobilization of reserves to the reproductive organs also occurs in sugar metabolism. The intense consumption of carbohydrates at the beginning of flowering for the formation of floriferous shoots results in the reduction these compounds contents (Cruz et al. 2007, Moreira et al. 2014).

Other important aspect of carbohydrate remobilization in stevia is its role in the composition of diterpene glycosides. After the formation of the steviol molecule, a series of glycosylations occur in the cytosol, which leads to the formation of the various sweetening compounds in the plant. These reactions are catalyzed by cytosolic UDPdependent glycosyltransferases (UGTs), enzymes that transfer a sugar residue from a donor (mainly UDP-glucose) to an acceptor molecule (Brandle and Telmer 2007, Ceunen and Geuns 2013c, Yang et al. 2015). In this way it is possible to infer that the decrease of the total sugar contents, observed at the beginning and full flowering, is also related to the greater biosynthesis of steviol glycosides.

In a study performed by Ceunen and Geuns (2013a) it was observed that ontogenetic variations in glucose levels were markedly different on short days and long days. During long days, the glucose content increased about two times in the beginning of the flower bud formation. In short days, however, the authors reported that there was stagnation or a small reduction in glucose contents, as observed in the present study for total sugars. This relation reinforces the hypothesis that the late planting greatly reduced the vegetative period of the crop, causing it to have a cycle and development model similar to that described for the species when submitted to cultivation on short days.
Concerning steviol glycosides, the higher contents per plant at the lower planting density might be related to the lower competition of plants for radiation, water and/or nutrients, as these factors are directly related to plant populations and are reported by several authors as important conditions for production of sweetening compounds in stevia (Jarma et al. 2012, Mandal et al. 2013, Pal et al. 2013, Kumar et al. 2012, 2014b, Parris et al. 2017). Considering the abovementioned relationship between chlorophyll $a$ and total chlorophyll contents and a higher photosynthetic capacity it is possible to infer that the best use of the radiation per individual promoted greater accumulation of precursors and energy for the biosynthesis of these molecules.

According to Brandle and Rosa (1992) the main factor affecting the content of diterpene glycosides in stevia is flowering. The content of sweetening compounds in stevia tends to increase until the beginning of flowering, decreasing continuously until the production of seeds, therefore, it is advisable to harvest the leaves at the beginning of the opening of the flowers (Kang and Lee 1981, Lima-Filho et al. 2004). Corroborating with these results, it is observed in the present work the reduction in both stevioside and rebaudioside $\mathrm{A}$ contents at the full flowering harvest, especially at higher planting density.

It seems to be a consensus that the physiological mechanisms associated with the ontogenetic variation in steviol glycosides accumulation involves a change in the transcription profile of the genes involved in the synthesis pathway (Ceunen and Geuns 2013a). According to Yang et al. (2015) most of the genes involved in steviol glycosides biosynthesis present expression peaks after the appearance of the floral bud, among them SrUGT74G1, which encodes the UGT responsible for stevioside synthesis. This ontogenetically regulated overexpression can be related with the higher contents of glycosides at the harvest at the 
beginning of flowering but does not explain the decreased level at full flowering.

Some hypotheses for reduction in steviol glycosides accumulation with the progress of flowering are related to the presence of senescent leaves with low levels of these metabolites (Kalandia et al. 2004), the remobilization to the reproductive organs (Bondarev et al. 2003), and/or even one catabolism in situ by endogenous glycosidases, although most of these assumptions have been recently refuted (Ceunen and Geuns 2013b). Accordingly the regulation of the production of these compounds appears to be a more complex mechanism that still need to be characterized (Yang et al. 2015).

Considering the industrial preference of rebaudioside A compared to stevioside, the endogenous rebaudioside $\mathrm{A} /$ stevioside ratio is an important factor to evaluate the quality of genetic material and cultivation practices for commercial extraction (Yadav et al. 2011, Ceunen and Geuns 2013c). The present study shows that the lowest ratio occurred at the pre flowering harvest and with the highest planting density. This behavior might be justified especially by the higher productivity of stevioside in this phase coupled with the greater competition between plants. A greater competition between plants can reduce the radiation availability per plant, and, consequently reduce photosynthesis (Jarma et al. 2010, Kumar et al. 2014b). Considering that the molecule of rebaudioside A bears one more glucose moiety in its structure in comparison with stevioside (Brandle and Telmer 2007, Ceunen and Geuns 2013a, c), a lower availability of glucose, a product from photosynthesis, can reduce the amount of rebaudioside $\mathrm{A}$ in relation to stevioside. A lower rebaudioside $\mathrm{A} /$ stevioside ratio was also related by Mandal et al. (2015) in plants with decreased photosynthetic rates.

Since stevioside is a direct precursor of rebaudioside $A$, there is a limitation in the bmetabolic flux of rebaudioside A by the levels of stevioside (Ceunen and Geuns 2013b). It is possible that the increase in rebaudioside $\mathrm{A}$ contents observed in the harvest at the beginning of flowering was a function of both the conversion of stevioside synthesized before the opening of the flowers, and not only of enzymatic regulation.

In relation to the stevioside accumulation, it was observed an increase in the beginning and full flowering harvests, as a function of the higher contents of the compounds in the beginning phase of flowering and the increase of the biomass accumulation in the full flowering phase. Regarding planting densities, the population of 166667 plants $\mathrm{ha}^{-1}$ promoted higher yields due to the greater accumulation of biomass per area.

For rebaudioside A yield, it was observed that the higher number of plants per area and harvesting at the beginning of flowering compensated for the better individual performance of the plants in the lower density, as observed by Serfaty et al. (2013) and by Kumar et al. (2014a), which reached a more than 2-fold increase in steviol glycoside accumulation in the density of 111 111plants ha ${ }^{-1}$ compared to lower density (37037 plants ha ${ }^{-1}$ ).

In a previous evaluation of the same accession under similar cultivation conditions (same region and soil conditions) a rebaudioside $\mathrm{A} /$ stevioside ratio of 0.95 and productivity of $695 \mathrm{~kg} \mathrm{ha}^{-1}$ of steviol glycosides was obtained in the first cut ( Francisco et al. 2018). This result is considerably higher than those reported in the present work. The previous discussed decrease in the vegetative period due to late planting may explain this drastic reduction and draw attention to the physiological and productive importance of the adequate planting period.

\section{CONCLUSIONS}

Harvesting at the beginning of flowering provides higher contents and yields of diterpene glycosides as a function of the dynamics of the biosynthesis flow 
of these compounds and the increase in biomass values. The adoption of a density of 166667 plants $\mathrm{ha}^{-1}$ associated to the harvest at the beginning of flowering promotes higher yields of biomass and steviol glycosides in the genotype evaluated in the present study.

\section{ACKNOWLEDGMENTS}

This study was financed in part by the Coordenação de Aperfeiçoamento de Pessoal de Nível Superior - Brasil (CAPES) - Finance Code 001 and Federal University of Parana. The authors would like to acknowledge the Brazilian company of agricultural research division of genetic resources and biotechnology (EMBRAPA-CENARGEN) for providing the genetic material, and the Laboratory of Pharmaceutical Technology (TECFARMA) from University of Southern Santa Catarina (UNISUL) for the steviol glycosides analysis. This article is part of the master's thesis of the first author.

\section{REFERENCES}

AHMED B, HOSSAIN M, ISLAM R, SAHA AK AND MANDAL A. 2011. A review on natural sweetener plant - Stevia having medicinal and commercial importance. Agron Glas 1: 75-92.

ARNON DI. 1949. Copper enzymes in isolated chloroplasts. Polyphenoloxidase in Beta vulgaris. Plant Physiol 24: $1-15$.

BARBET-MASSIN C, GIULIANO S, ALLETTO L, DAYDÉ J AND BERGER M. 2015. Nitrogen Limitation Alters Biomass Production but Enhances Steviol Glycoside Concentration in Stevia rebaudiana Bertoni. PLoS One 10: $1-16$.

BASUKI S.1990. Effects of black plastic mulch and plant density on the growth of weeds and stevia. Biotrop 38 : 107-108.

BONDAREV NI, SUKHANOVA MA, RESHETNYAK OV AND NOSOV AM. 2003. Steviol glycoside content in different organs of Stevia rebaudiana and its dynamics during ontogeny. Biol Plant 47: 261-264.

BRADFORD MM. 1976. A Rapid and Sensitive Method for the Quantitation of Microgram Quantities of Protein Utilizing the Principle of Protein-Dye Binding. Anal Biochem 72: 248-254.
BRANDLE JE AND ROSA N. 1992. Heritability for yield, leaf:stem ratio and stevioside content estimated from a landrace cultivar of Stevia rebaudiana. Can J Plant Sci 72: 1263-1266.

BRANDLE JE AND TELMER P. 2007. Steviol glycoside biosynthesis. Phytochemistry 68: 1855-1863.

BRASIL. 2017. Ministério do Desenvolvimento, Indústria e Comércio Exterior, Secretaria do Comércio Exterior. Programa AliceWeb. Available online from: <http:// aliceweb.desenvolvimento.gov.br>. Accessed on May 2, 2017.

BREDEMEIER C AND MUNDSTOCK CM. 2000. Regulação da absorção e assimilação do nitrogênio nas plantas. Cienc Rural 30: 365-372.

CEUNEN S AND GEUNS JMC. 2013a. Glucose, sucrose, and steviol glycoside accumulation in Stevia rebaudiana grown under different photoperiods. Biol Plant 57: 390394.

CEUNEN S AND GEUNS JMC. 2013b. Influence of photoperiodism on the spatio-temporal accumulation of steviol glycosides in Stevia rebaudiana (Bertoni). Plant Sci 198: 72-82.

CEUNEN S AND GEUNS JMC. 2013c. Steviol Glycosides: Chemical Diversity, Metabolism, and Function. J Nat Prod 76: 1201-1228.

CHAPPELLE EW AND KIM MS. 1992. Ratio analysis of reflectance spectra (RARS): an algorithm for a remote estimation of the concentrations of chlorophyll $A$, chlorophyll $B$, and carotenoids in soybean leaves. Remote Sens Environ 39: 239-247.

COMISSÃO DE QUÍMICA E FERTILIDADE DO SOLO. 2004. Manual de adubação e de calagem para os estados do Rio Grande do Sul e Santa Catarina, $10^{\text {th }}$ ed., Porto Alegre: Sociedade Brasileira de Ciência do Solo, 400 p.

CRUZ MCM, SIQUEIRA DL, SALOMÃO LCC, CECON PR AND SANTOS D. 2007. Teores de carboidratos em limeiras ácidas 'Tahiti' tratadas com paclobutrazol. Rev Bras Frut 29: 222-226.

DAS A, GANTAIT S AND MANDAL N. 2011. Micropropagation of an elite medicinal plant: Stevia rebaudiana Bert. Int J Agric Res 6: 40-48.

DONALÍSIO MGR, DUARTE FR, PINTO AJ AND SOUZA CJ. 1982. Estévia. Agronômico 34: 65-68.

DUBOIS M, GILLES KA, HAMILTON JK, REBERS PAAND SMITH F. 1956. Colorimetric method for determination of sugars and related substances. Anal Biochem 28: 350-356.

FRANCISCO F, PEREIRA GP, MACHADO MP, KANIS LA AND DESCHAMPS C. 2018. Characterization of Stevia rebaudiana Bertoni Accessions Cultived in Southern Brazil. J Agric Sci 10: 353-363.

FUTURE MARKET INSIGHTS. 2014. Stevia Market: Global Industry Analysis and Opportunity Assessment 2014 - 2020. Available online from: <http://www. 
futuremarketinsights.com/reports/global-stevia-market>. Accessed on May 02, 2017.

GONZÁLEZ HR, LUZ LLA, SOSA IH, AMITA MMR, FERRADÁ CAR, GOVÍN ES AND FIGUEREDO MM. 2007. Comportamiento del cultivo de Stevia rebaudiana (Bertoni) Bertoni en Cuba. RCPM 12: 1-5.

GULERIA P, MASAND S AND YADAV SK. 2014. Overexpression of SrUGT85C2 from Stevia reduced growth and yield of transgenic Arabidopsis by influencing plastidial MEP pathway. Gene 539: 250-257.

IMSANDE J AND TOURAINE BN. 1994. Demand and regulation of nitrate uptake. Plant Physiol 105: 3-7.

JAIN P, KACHHWAHA S AND KOTHARI SL. 2009. Improved micropropagation protocol and enhancement in biomass and chlorophyll content in Stevia rebaudiana (Bert.) Bertoni by using high copper levels in the culture medium. Sci Hort 119: 315-319.

JARMA AO, CARDONA AYALA C AND FERNÁNDEZ HERRERA C. 2012. Temperature and radiation effect on steviol glycosides production in Stevia rebaudiana in the Colombian humid Caribbean region. Revista UDCA Actualidad \& Divulgación Científica 15: 339-347.

JARMA AO, CARRANZA CG AND CLAVIJO JP. 2010. Captación y uso de la radiación en plantas de estevia (Stevia rebaudiana Bert.) en el Caribe colombiano. Agron Colomb 28: 37-46.

JARMA AO, RENGIFO T AND ARAMÉNDIZ H. 2006. Fisiología de estevia (Stevia rebaudiana Bertoni) en función de la radiación en el Caribe colombiano. II. Análisis de crecimiento. Agron Colomb 24: 38-47.

KALANDIA A, PAPUNIDZE G, VANIDZE M AND PAPUNIDZE S. 2004. HPLC of Stevia (Stevia rebaudiana Bertoni) diterpene glycosides. Bull Georgian Acad Sci 169: 147-150.

KANG KH AND LEE EW. 1981. Physio-ecological studies on Stevia (Stevia rebaudiana Bertoni). Korean J Crop Sci 26: 69-89.

KOLB N, HERRERA JL, FERREYRA DJ AND ULIANA RF. 2001. Analysis of Sweet Diterpene Glycosides from Stevia rebaudiana: Improved HPLC Method. J Agric Food Chem 49: 4538-4541.

KÖPPEN W. 1931. Grundriss Der Klimakunde, $1^{\text {st }}$ ed., Berlin: W. Guyter, 390 p.

KUMAR R, SHARMA S, RAMESH K, PRASAD R, PATHANIA V, SINGH B AND SINGH RD. 2012. Effect of agrotechniques on the performance of natural sweetener plant - Stevia (Stevia rebaudiana Bertoni) under western Himalayan conditions. Ind J Agron 57:74-81.

KUMAR R, SHARMA S AND SOOD S. 2014a. Yield components, light interception and marker compound accumulation of stevia (Stevia rebaudiana Bertoni) affected by planting material and plant density under western Himalayan conditions. Arch Agron Soil Sci 60: 1731-1745.

KUMAR R, SOOD S, SHARMAS, KASANARC, PATHANIA VL, SINGH B AND SINGH RD. 2014b. Effect of plant spacing and organic mulch on growth, yield and quality of natural sweetener plant Stevia and soil fertility in western Himalayas. Int J Plant Prod 8: 311-334.

LADYGIN VG, BONDAREV NI, SEMENOVA GA, SMOLOV AA, RESHETNYAK OV ANDA NOSOV AM. 2008. Chloroplast ultrastructure, photosynthetic apparatus activities and production of steviol glycosides in Stevia rebaudiana in vivo and in vitro. Biol Plant 52: 9-16.

LAMBERS H, CHAPIN FS AND PONS TL. 2008. Plant physiological ecology, $2^{\text {nd }}$ ed., New York: Springer, 610 p.

LEMUS-MONDACA R, VEGA-GÁLVEZ A, ZURABRAVO L AND AH-HEN K. 2012. Stevia rebaudiana Bertoni, source of a high-potency natural sweetener: A comprehensive review on the biochemical, nutritional and functional aspects. Food Chem 132: 1121-1132.

LIMA-FILHO OF. 2004. Análise Quantitativa do Crescimento da Estévia, $1^{a}$ ed., Dourados: Empresa Brasileira de Pesquisa Agropecuária (Embrapa), 27 p.

LIMA-FILHO OF, VALOIS ACC AND LUCAS ZM. 2004. Sistemas de Produção 5: Estévia, $1^{a}$ ed., Dourados: Empresa Brasileira de Pesquisa Agropecuária (Embrapa), $55 \mathrm{p}$.

MADAN S, AHMAD S, SINGH GN, KOHLI K, KUMAR Y, SINGH R AND GARG M. 2010. Stevia rebaudiana (Bert.) Bertoni - A Review. Indian J Nat Prod Resour 1: 267-286.

MANDAL S, EVELINA H, GIRI BB, SINGHA VP AND KAPOOR R. 2013. Arbuscular mycorrhiza enhances the production of stevioside and rebaudioside-A in Stevia rebaudiana via nutritional and non-nutritional mechanisms. Appl Soil Ecol 72: 187-194.

MANDAL S, UPADHYAY S, SINGH VP AND KAPOOR R. 2015. Enhanced production of steviol glycosides in mycorrhizal plants: a concerted effect of arbuscular mycorrhizal symbiosis on transcription of biosynthetic genes. Plant Physiol Biochem 89: 100-106.

MASCLAUX-DAUBRESSE C, DANIEL-VEDELE F, DECHORGNAT J, CHARDON F, GAUFICHON L AND SUZUKI A. 2010. Nitrogen uptake, assimilation and remobilization in plants: challenges for sustainable and productive agriculture. Ann Bot 105: 1141-1157.

MEJEGI NW, KUMAR JK, SINGH V, KAUL VK AND AHUJA PS. 2005. Introducing Stevia rebaudiana, a natural zero-calorie sweetener. Curr Sci 88: 801-804.

MENDES MM, GAZARINI LC AND RODRIGUES ML. 2001. Acclimation of Myrtus communis to contrasting Mediterranean light environments - effects on structure and chemical composition of foliage and plant water relations. Environ Exp Bot 45: 165-178. 
MORAES RM, DONEGA MA, CANTRELL CL AND MCCHESNEY JD. 2013. Effect of harvest timing on leaf production and yield of diterpene glycosides in Stevia rebaudiana Bert: A specialty perennial crop for Mississippi. Ind Crops Prod 51: 385-389.

MORDOR INTELLIGENCE. 2017. Stevia Market - Growth, Trends and Forecasts (2017 - 2022). Available online from: <https://www.mordorintelligence.com/industryreports/stevia-market?gclid=CM7fqtn79dMCFU4JkQ od_FQA5Q $>$ Accessed on May 15, 2017.

MOREIRA RA, CRUZ MCM, FAGUNDES MCP, PANTOJA LA AND SANTOS AS. 2014. Carboidratos foliares durante a floração e os estádios iniciais de crescimento de frutilhos em tangerineira 'Ponkan'. Pesq Agropec Bras 49: 34-39.

PAL PK, MAHAJAN M, PRASAD R, PATHANIA V, SINGH N AND AHUJA PS. 2015. Harvesting regimes to optimize yield and quality in annual and perennial Stevia rebaudiana under sub-temperate conditions. Ind Crops Prod 65: 556564.

PAL PK, PRASAD R AND PATHANIA V. 2013. Effect of decapitation and nutrient applications on shoot branching, yield, and accumulation of secondary metabolites in leaves of Stevia rebaudiana Bertoni. J Plant Physiol 170: 15261535.

PARRIS CA, SHOCK CC AND QIAN M. 2017. Soil Water Tension Irrigation Criteria Affects Stevia rebaudiana Leaf Yield and Leaf Steviol Glycoside Composition. HortScience 52: 154-161.

RÊGO GM AND POSSAMAI E. 2004. Avaliação dos teores de clorofila no crescimento de mudas de Jequitibá-Rosa (Cariniana legalis), $1^{\mathrm{a}}$ ed., Colombo: Empresa Brasileira de Pesquisa Agropecuária (Embrapa), 4 p.

PORRA RJ, THOMPSON WAAND KRIDEMANN PE. 1989. Determination of accurate extinction coefficients and simultaneous equations for assaying a and b extracted with four different solvents: verification of the concentration of chorophylls standards by atomic absorption spectroscopy. Biochim Biophys Acta 975: 384-394.

REIS AR, FAVARIN JL, GALLO LA, MALAVOLTA E, MORAES MF AND LAVRES JUNIOR J. 2009. Nitrate reductase and glutamine synthetase activity in coffee leaves during fruit development. Rev Bras Cienc Solo 33: 315-324.

SERFATY M, IBDAH M, FISCHER R, CHAIMOVITSH D, SARANGA Y AND DUDAI N. 2013. Dynamics of yield components and stevioside production in Stevia rebaudiana grown under different planting times, plant stands and harvesting regimes. Ind Crops Prod 50: 731736.

SILVA FAS AND AZEVEDO CAV. 2016. Comparison of means of agricultural experimentation data through different tests using the software Assistat. Afr J Agric Res 37: 3527-3531.

TALEIE N, HAMIDOGHLI Y, RABIEI B AND HAMIDOGHLI S. 2012. Effects of plant density and transplanting date on herbage, stevioside, phenol and flavonoid yield of Stevia rebaudiana Bertoni. Intl J Agri Crop Sci 4: 298-302.

WU J, WANG Y AND LIN X. 2013. Purple Phototrophic Bacterium Enhances Stevioside Yield by Stevia rebaudiana Bertoni via Foliar Spray and Rhizosphere Irrigation. PLoS One 8: 1-5.

XU G, FAN X AND MILLER AJ. 2012. Plant nitrogen assimilation and use efficiency. Annu Ver Plant Biol 63:153-182.

YADAV AK, SINGH S, DHYANI D AND AHUJA PS. 2011. A review on the improvement of stevia [Stevia rebaudiana (Bertoni)]. Can J Plant Sci 91: 1-27.

YANG Y, HUANG S, HAN Y, YUAN H, GU C AND WANG Z. 2015. Environmental cues induce changes of steviol glycosides contents and transcription of corresponding biosynthetic genes in Stevia rebaudiana. Plant Physiol Biochem 86: 174-180. 